\title{
Investigation of formulation preparation of two plant extracts and determination of the effectiveness on Tetranycus urticae Koch.(Arachnida:Tetranychidae)
}

\begin{abstract}
In this study fruits extracts of Melia azederach L. (Meliaceae) and Allium sativum L. (Amarylliaceae) were prepared and formulation studies of these extracts were carried out with several inert ingredients. The quality tests of these extracts were performed. According to the results of these tests, preparations, which were found successfully, were separated/ chosen for effectiveness studies on Tetranycus urticae Koch. The acaricidal effect of the formulations/preparates were carried out on T. urticae by using leaf dipping method under laboratory conditions. Effects of prepared formulations at three different concentrations $(5,7,10 \mathrm{ml} / \mathrm{L})$ were determined on T. urticae. According to the results of laboratory studies, the highest dose found to be effective and theirs two upper doses $(10,15,20 \mathrm{ml} / \mathrm{L})$ were taken to examine effect on mites at the greenhouse conditions. Each plot consists of 10 plants. When the density of mite population 1-3 live individual/leaf, the plants were sprayed. Counts were carried out before application of formulations and after application 1, 3 and 7 days. Neem Azal T/S was applied as standard in greenhouse trials. The highest effect was at the highest dose of extract of M. azedarach $(88.42 \%)$. Similar results were obtained in greenhouse trials.
\end{abstract}

Keywords: formulations, Two-spotted spider mite, acaricidal activity, plant extracts
Volume 3 Issue 3 - 2019

\author{
Pervin Erdogan, 'Gamze Esin Kilinc,' Pelin \\ Aksu,' Murat Kahyaoglu² Numan Ertugrul \\ Babaroglu' \\ 'Plant Protection Central Research Institute, Turkey \\ ${ }^{2}$ Agriculture and Chemical industry Trade Corporation, Turkey
}

Correspondence: Pervin Erdogan, Plant Protection Central Research Institute, Ankara, Gayret Mah. Fatih Sultan Mehmet Bul. 66,Yenimahalle,Ankara,Turkey,

Email pervin.erdogan@tarimorman.gov.tr

Received: May 07, 2019 | Published: June 10, 2019

\section{Introduction}

Vegetables are grown in both greenhouse and field conditions in almost all regions and it constitutes $95 \%$ of the total greenhouse in Turkey. ${ }^{1}$

The spider spotted mite, Tetranychus urticae Koch (Acarina:Tetranychidae) is one of the most important pests responsible for yielding losses to many horticultural ornamental and agronomic crops. It has been reported that the mite has attacked about 1200 species of plants, of which more than 150 are economically significant. ${ }^{2}$ It is revealed that T. urticae causes remarkable economic loss by reaching high density. ${ }^{3}$ T. urticae fed by puncturing and draining the contents, producing a characteristic yellow speckling on the leaf surface. They also produce silk webbing which is clearly visible at high infestation levels. ${ }^{4}$ The mites feeding causes graying or yellowing of the leaves and $40-60 \%$ loss of product In addition, it causes the spread of various virus diseases. ${ }^{5}$

Synthetic pesticides are generally utilized against the two spotted spider mite, as they are easy to apply, effective. However, using pesticides for a long time causes an ecological imbalance, side effects on natural enemies, and environmental pollution. ${ }^{6}$ The mite is also difficult to control due to their resistance to many commonly used pesticides. ${ }^{7,8}$

Because of the adverse effect of pesticide use, alternative control methods are being researched for T.urticae. Some of the alternative control methods including acaricidal effects of the plant essential oils, plant preparations and microbial secondary metabolites on T.urticae are currently being researched.$^{9-11}$ There are so many studies about effect the extracts of $M$. azedarach and A. sativum. It was determined that the extracts $M$. azedarach showed strong antifeeding effect and ovicidal effect on Leptinotarsa decemlineata Say (Col.:
Chrysomelidae)..$^{12,13}$ Erdogan et al..$^{14}$ reported that the extracts of $A$. sativum had the highest mortality rate on T. urticae.

Many studies have been conducted to search for alternative chemical pesticides in our country and studies are continuing. However, most of the studies have remained in the research stage and there are no biopesticides recorded to the application. Especially in organic agriculture where chemical pesticides are not allowed to be used, biopesticides have been needed to control pests. All recorded biopesticides are overseas and have no biopesticides available for each product. In our country, which has a very rich flora, it is important to study on biopesticides of plants origin, and to evaluate the research results in a way to be applied to this subject. The application of biopesticides obtained from local sources and plant origin substances is expected to fill the gap in the area of organic agriculture, integrated products and good agricultural practices and will significantly contribute to the national economy.

The aim of this study was to determine the insecticidal effects of the extracts obtained from A. sativum and M. azederach and the formulations prepared against $T$. urticae

\section{Materials and methods}

\section{Plants material}

Plants used in the study were gathered from three different the provinces during 2016. M. azedarach was collected from Adana province, A. sativum was collected Kastamonu. Both of plants were used their frits to prepare extracts.

\section{Preparing the extracts}

Plants and fruits collected for extract preparation dried for 3-4 days without being exposed to sunlight and then grinded with mill. 
Dried fruit and plants weighed $100 \mathrm{~g}$ into the glass, and then ethanol $(99.9 \%$ purity) was added to flasks with $1: 8(\mathrm{w} / \mathrm{v})$ ratio. The samples were extracted with a direct solvent under reflux in a water bath set at $60{ }^{\circ} \mathrm{C}$ for two hours. At the end of two hours, the extract was filtered through a filter paper and then taken out of the glass balloon. Ethanol was added to the remain part with the same ratio $1: 8(\mathrm{w} / \mathrm{v})$ and extracted for another two hours in a water bath set at $60^{\circ} \mathrm{C}$ for complete extraction of phenolic components. After two hours the second extract was filtered through a filter paper to the same glass balloon. The solvent of the extract was evaporated to dryness in a vacuum rotary evaporator at $60^{\circ} \mathrm{C} . .^{15,16}$ Three-five grams of extract were obtained from a total of $100 \mathrm{~g}$ of dry matter.

\section{Formulation preparation of extracts}

The solubility of the extract with the appropriate solvents was determined based on the physicochemical properties of the components contained in the extract. The determination of the appropriate solvent was made by the method proposed by Flanagan ${ }^{17}$ According to the method, $1.20 \mathrm{~g}$ of extract was weighed into the test tube and 2 or 2 parts by volume of oil, water or appropriate solvents were added in the form of a maximum of $10 \mathrm{ml}$ of water. After each $2 \mathrm{ml}$ of solvent addition, the test tube was heated and stirred in a magnetic stirrer. If the amount of added solvent reached to $10 \mathrm{ml}$ and dissolution did not occurred, then another solvent was tried by removing the former solvent from the experiments. In this way by using different vegetable oils as solvent the most suitable solvent was chosen to dissolve the extract and most suitable formulation type was selected. Extract was stirred at $800 \mathrm{rpm}$ in a vertical mixer together with a suitable solvent and co-formulates by taking into account the physical and chemical properties of the extract, and then stirred at $4500 \mathrm{rpm}$ for 1.5 hours in a high-speed vertical mixer until the fineness degree reaches 1020 microns and a homogeneous distribution was obtained. Thus, homogeneous distribution of the insoluble components in the extract is achieved. The products taken into the resting tank were left for 24 hours and subjected to quality control analyzes.

\section{Quality control analysis}

It was conducted quality control tests (as recommended by the Food and Agriculture Organization of the United Nations (FAO) and the World Health Organization (WHO) for Suspension concentrate (SC) formulation. ${ }^{18}$

\section{Physical analyzes}

Appropriate analyzes of the obtained Suspension Concentrate (SC) formulation were carried out in the Institute's laboratories using CIPAC analysis methods, taking into account the FAO (Food and Agriculture Organization) Criteria.

Aspect: The Suspension Concentrate (SC) formulation we have prepared has been determined to be a heterogeneous suspension (viscous liquids) with a uniform color and a homogeneous structure when shaken. Once the product has been appropriately agitated, the bottom is checked with a stick and it is observed that it does not contain any layer or precipitate. This method has been realized visually. ${ }^{18}$

Specific gravity (density): The specific weight of the prepared formulation was determined by the digital densmeter in our laboratory. It was waited for the device would become ready by making its own calibration after it is turned on via the power button. The air of the sample taken into the syringe was taken and given to the collar through the inlet of the sample-measuring chamber. Measurement button was turned on and waited for the result message on the screen and the results were recorded.

Wet sieve test: The wet sieve test was performed according to CIPAC MT 185.

Suspension capability: The suspension capability test was conducted in according to CIPAC MT 184.

\section{T. urticae culture}

T. urticae was reared in the laboratory at $25 \pm 1{ }^{\circ} \mathrm{C}$ and under long daylight (18 light: 6 dark) and $65-70 \%$ relative humidity on potted bean. The bean plants (Phaseolus vulgaris L.) used in the experiment all were grown in greenhouse.

\section{Effect of the extracts on T. urticae}

\section{Dose-mortality tests}

Leaf-Dipping Method; from untreated bean leaves $3 \mathrm{~cm}$ in diameter disc was punched out. These discs were then dipped into the test solutions (formulations prepared of extracts 1,3, 5, 7 and $10 \mathrm{ml} / \mathrm{L}$ ) for one minute. The control disc was dipped in $0.01 \%$ Triton X-100 solution. Then left to dry for 30 minutes. The treated leaf discs were placed into petri dishes, which lined with moistened filter paper. Then 10 adults and larva of $T$. urticae were introduced onto the treated discs in separate petri dishes. Same procedure was used for control. ${ }^{19}$ The experiment was replicated 10 times including control. For each petridish contained 10 adult 3 days old first larval stage was used. Data collection started after 1,3 , and 6 days by counting the number of living larvae and adults. The experiments were conducted in a climate chamber at $25 \pm 1{ }^{\circ} \mathrm{C}$ and under long daylight (18:6 light: dark).

\section{The experiments of greenhouse}

Effective doses $(10 \mathrm{ml} / \mathrm{l})$ and two top doses $(15,20 \mathrm{ml} / \mathrm{l})$ of the extract obtained from M. azederach and A. sativum plants which was effectively determined in laboratory conditions have been tried in the greenhouse in the Institute garden $(100 \mathrm{~m} 2)$. Bean seeds planted in greenhouse on August 3, 2015 and when the bean plants come to 5-6 leaf each plant was left with leaves that were infested with $T$. urticae plants and plants which infested with harmful.

The experiment was set up according to the experiment design of randomize plot. The experiment was replicated 5 times including control. The size of each plot was $5 \mathrm{~m}^{2}$ and each plot included 10 bean plants. Applications were carried out with on September 14, 2015. When at least approximately 3 larva, nymph, adult/leaf the plants were sprayed using a hand held sprayer. Neem Azal T/S (\%1 azadirachtin, $500 \mathrm{ml} / 100$ liter water) was applied as positive control. The amount of water required for each plot was determined by calibrating before application. About 100-125 ml of water was used for each plant. The applications were made to wet all sides of the plant.

Leaf counts were made directly on each leaf $4 \mathrm{~cm}^{2}\left(2 \mathrm{~cm}^{2}+2 \mathrm{~cm}^{2}\right)$. Before the sample was taken, the plot was observed and the lower, middle and upper leaves of the plant to represent the harmful population were determined in advance. At least 10 leaves were taken from each plot and the leaves were brought to the laboratory and counted under binoculars. Counts were made before application and 1,3 and 7 days after application. ${ }^{20}$ 


\section{Statically analysis}

The effect was calculated according to Abbott. ${ }^{21}$ The obtained results were submitted to a variance analysis and the mean values were compared by Duncan's test $(\mathrm{P}=0.05)$ calculated by the program SPSS 20.6. For statistical analysis greenhouse study was used the formula Henderson-Tilton. ${ }^{22}$

\section{Results and discussion}

\section{Quality control analysis}

Suspended Concentrate (SC) formulations prepared from extracts were subjected to quality control analyzes such as appearance, specific gravity, suspension ability and fineness. Viscosity tests could not be carried out because samples could not be obtained in sufficient quantities.

The formulation type SC of (Suspension Concentrate) the extract obtained from $M$. azederach had a brownish black liquid appearance. The specific weight (density) was $1,050 \mathrm{~g} / \mathrm{ml}$. Suspension ability (CIPAC MT 184) results are 101\%; (WHO) was found to pass completely through the 75 micron elec-trode. The formulation type of the extract obtained from A. sativum was SC (Suspension Concentrate). Appearance is yellow-light brown with specific gravity (density) value of $1,020 \mathrm{~g} / \mathrm{ml}$. Suspension ability (CIPAC MT 184) results are 103\%; It was determined that the depth grade test (WHO) passes completely through the 75 micron mesh.

\section{Dose-mortality tests}

Leaf dipping method was used to determine the acaricidal effect of the formulations/prepares on T. urticae in under laboratory conditions. Data is given in Table 1.

As shown in Table 1. The highest effect was at the highest concentration $10 \%$ while the smallest effect was $1 \%$ in all extracts of plants. The effect increased depending on doses. It was determined that the highest effect was extract of $M$. azederach concentration $10 \%$. Statistical analysis showed importance differences between the concentrations ( $\mathrm{F}=57.14 ; \mathrm{P}=0.00)$.

Table I The acaricidal effects of obtained from three different plants on Tetranychus urticae Koch

\begin{tabular}{|c|c|c|}
\hline $\operatorname{Doses}(\mathrm{ml} / \mathrm{L})$ & $\begin{array}{l}\text { Melia azederach L. } \\
\text { Effect (\%) }\end{array}$ & Allium sativum L. \\
\hline I & $14.69 \pm 2.04 \mathrm{~d}$ & $13.65 \pm 1.73 \mathrm{~d}$ \\
\hline 3 & $28.88 \pm 6.78 \mathrm{c}$ & $19.44 \pm 3.63 \mathrm{~d}$ \\
\hline 5 & $50.69 \pm 4.05 c$ & $48.56 \pm 5.13 \mathrm{c}$ \\
\hline 7 & $68.74 \pm 2.08 b$ & $67.5 \mathrm{I} \pm 3.07 \mathrm{~b}$ \\
\hline 10 & $88.42 \pm 2.88 \mathrm{a}$ & $76.28 \pm 2.91 \mathrm{a}$ \\
\hline
\end{tabular}

$($ Mean \pm SE)*

*Means within rows followed by the same uppercase letter are not significantly different (Duncuns's multiple range test).

\section{The experiments of greenhouse}

The dose of $M$. azederach and A.sativum extract, which has an effect of more than $75 \%$ in the laboratory conditions, and the two upper doses were tested in under greenhouse conditions. The results are given in Table 2 .

According to Table 2, the highest dose of $M$. azederach extract showed the highest dose at day 7 . The lowest effect was determined on the 1st day at the lowest dose. According to the statistical analysis, at the last count all doses were in the same group. It was determined that obtained from $A$. sativum extract had the highest effect was at the highest dose in the count on the 7th day. According to the statistical analysis, in the last counts, all doses formed the same group. Neem Azal T/S showed higher efficacy than all extracts $(\mathrm{F}=4.173 ; \mathrm{P}=0.00)$.

Table 2 The acaricidal effects of obtained from three different plants on Tetranychus urticae Koch. (Mean \pm SE)(Greenhouse)

\begin{tabular}{|c|c|c|c|c|}
\hline \multirow{3}{*}{ Treatments } & \multirow{3}{*}{$\begin{array}{l}\text { Doses } \\
(\mathrm{ml} / \mathrm{l})\end{array}$} & \multicolumn{3}{|l|}{ Count times } \\
\hline & & $\begin{array}{l}\text { I st day } \\
(15.9 .20 \mid 7)\end{array}$ & $\begin{array}{l}\text { 3rd day } \\
(17.9 .20 \mid 7)\end{array}$ & $\begin{array}{l}\text { 7th day } \\
(24.9 .2017)\end{array}$ \\
\hline & & \multicolumn{3}{|l|}{ Effect (\%) } \\
\hline \multirow{3}{*}{ M. azederach } & 10 & $35.53 \pm 2.34 b^{* *} C^{*}$ & $49.87 \pm 2.27$ b B & $63.26 \pm 1.57 \mathrm{bA}$ \\
\hline & 15 & $69.91 \pm 1.41$ a B & $72.06 \pm 4.00$ a B & $81.92 \pm 1.22 \mathrm{a} \mathrm{A}$ \\
\hline & 20 & $75.12 \pm 1.65$ a B & $81.17 \pm 3.12$ a B & $85.16 \pm 1.93$ a A \\
\hline \multirow{3}{*}{ A. sativum } & 10 & $26.34 \pm 2.73$ с B & $47.01 \pm 1.69 \mathrm{cA}$ & $51.09 \pm 0.92 \mathrm{cA}$ \\
\hline & 15 & $39.5 I \pm 1.35$ b C & $56.70 \pm 1.62$ b B & $72.6 \mathrm{I} \pm 1.37 \mathrm{bA}$ \\
\hline & 20 & $62.40 \pm 1.44$ a C & $72.28 \pm 1.36$ a B & $77.23 \pm 1.83$ a A \\
\hline Neem Azal T/S & $\begin{array}{l}500 \\
\mathrm{ml} / \mathrm{I} 00 \\
\mathrm{IW}\end{array}$ & $69.33 \pm 2.62 \mathrm{C}$ & $86.37 \pm 1.90 \mathrm{~B}$ & $94.38 \pm 0.62 \mathrm{~A}$ \\
\hline
\end{tabular}

*Means within rows followed by the same uppercase letter are not significantly different (Duncuns's multiple range test).

**Means within column followed by the same lowercase are not significantly different (Duncuns's multiple range test). 
Several plants were found to contain bioactive compounds with a variety of biological actions against insects, including repellent, antifeedant, anti-ovipositional, toxic, chemosterilant and growth regulatory activities. ${ }^{23,24}$ The use of plant derivatives as an alternative to chemical insecticides was studied throughout the World. Over 20009 plant species were reported to possess pest control properties. ${ }^{25}$ There are many of studies on effect of plant extracts on insects, but there are few of formulated product from obtained plants. The most important of these plants is Azadirachta indica (A. Juss). ${ }^{26}$ Schmutterer ${ }^{27}$ determined that the extracts obtained from $A$. indica had different effects on many pests. The extracts of $A$. indica had such as melianone. melianol. 14-epoxyazadiradione, azadiradone, azadirone, gedunin that had effect antifeeding, repellent. oviposition deterrent. As a result of our work, it was revealed that the extracts of $M$. azedarach showed the highest effect on T. urticae. There are studies in parallel with our study results. For example, Dimetry et al. ${ }^{28}$ determined that commercial products named Margosan- 0 and Neem Azal S obtained from neem seed extracts had a high mortality rate and reduction in the number of eggs laid on T. urticae. Additionally, it was revealed that Margosan-O and Neem Azal S caused rate of mortality $50 \%$ on $T$. urticae..$^{29}$ It was observed that pure azadirachtin showed that had antifeeding effect and the number laid decreasing on T. urticae.$^{30}$ Currently there are preparations named Margosan-O, Azatin, Bioneem, Neemguard and Neem Azal T/S developed from extract of $A$. indica. In addition, It was determined that the extract of $M$. azedarach and A. sativum showed acaricidal effect and deterrent oviposition on T. urticae. ${ }^{14}$ Similarly, Dobrowski and Seredynska ${ }^{31}$ revealed that the extracts of A. sativum caused of mortality at 48$57 \%$ on T. urticae. M. azederach is the same family Neem tree and contains the same active ingredients. ${ }^{32}$ The azadirachtin obtained from A. indica was taken into preparation in the world and in our country and was recommended against many pests.

\section{Conclusion}

As a result, it was revealed that the plants extracts obtained from obtained M. azedarach and A. sativum fruit the formulations/prepares were acaricidal effect on T. urticae in the greenhouse conditions. The studies on extraction and preparation of the formulation were carried out pilot scale in the laboratory conditions. It is considered to perform the production of the formulations which is recommended in largescale production facilities and to subject them to quality control tests. More research is required to develop this initial study further.

\section{Acknowledgments}

This work was supported by the General Directorate of Agricultural Research and Policies. Project No: TAGEM-BS-12/09-07/01-14.

\section{Conflicts of interest}

Conflict of interest Authors declares there is no conflict of interest.

\section{References}

1. Anonymous, http://www.boyutft.com/nemguard.php 2017.

2. Zhang Z. Mites of Greenhouses; Identification. Biology and Control. Wallingford. CABI Publishing. UK;2003.

3. Tsagkarakou A, Navajas M, Rousser F, et al. Genetic differentiation in tetranychus urticae (Acari: Tetranychidae) from greenhouses in France. Exp Appl Acarol. 1999;(23):365-378.
4. Jeppson LR, Keifer HH, Baker EV. Mites Injurious to Economic Plants-1. Berkeley: University of California Press. 1975;383.

5. Thomas CE. Transmission of tobacco ringspot virus by Tetranychus $\mathrm{sp}$. Phytopathology. 1969;59:633-636.

6. Van Leeuwen TV, Tirry L, Nauen R. Complete maternal inheritance of bfenazate resistance in tetranychus urticae (acari: tetranychidae) and its implications in mode of action considerations. Insect Biochhemistry and Moleculer Biology. 2006;36:869-877.

7. Cranham JLF, Helle. Pesticide resistance in tetranychidae. In spider mites their biology. Natural enemies and control. Helle W \& Sabelis MW. editors. Amsterdam: Elsevier. 1985;405-422.

8. Shen HM. Resistance and cross-resistance of tetranychus viennensis (Acari: Tetranychidae) to 14 insecticides and acaricides. Syst Appl Acarol. 1999;4:9-14.

9. Calmasur O, Aslan I, Sahin F. Insecticidal and acaricidal effect of three lamiaceae plant essential oils against tetranychus urticae koch. Bemisia tabaci Genn. Ind Crop Prod. 2006;23:140-146.

10. Shi GL, Zhao LL, Liu SQ, et al. Acaricidal activities of extracts of kochia scoparia against tetranychus urticae. tetranychus cinnabarinus and tetranychus viennensis (Acari: Tetranychidae). J Econ Entomol. 2006;99:858-863.

11. Villanueva RT, Walgenbach JF. Acaricidal Properties of spinosad against tetranychus urticae and pnonychus ulmi (Acari: Tetranychidae). J Econ Entomol. 2006;99(3):843-849.

12. Erdogan P, Toros S. The effects of Melia azedarach L. Extracts on development on larvae of colorado potato beetle [Leptinotarsa decemlineata Say (Col.:Chrysomelidae)] Plant Protection Bulletin. 2006;45:(1-4):99-119.

13. Erdogan P, Toros S. The antifeeding effect of Melia azedarach L. (Meliaceae) extracts Colorado potato beetle [(Leptinotarsa decemlineata Say. Col.:Chrysomelidae). 2006. IVth national potato congressl 06-08 September, Nigde, 2006b;276-279.

14. Erdogan P, Yildirim A, Sever B. Investigations on the effects of five different plant extracts on the two-spottedmite tetranychus urticae koch (Arachnida: Tetranychidae). Hindawi Publishing Corporation Psyche. 2012;125284:5

15. Gur E. Investigation of antioxidative effects of oregano extracts in refined olive oil. Ege Univesity. Graduate School of Natural and Applied Sciences. M.Sc. Thesis. İzmir. 1995;78 p.

16. Sengun. P. Investigation of antioxidant activity in sunflower oil of rosemary extracts obtained by supercritical-CO2 Extraction. Ege University. Graduate School of Natural and Applied Sciences Graduate Thesis. Izmir. 2001;118 p.

17. Flanagan J. Principles of pesticide formulation. Industrial production and formulation of pesticides indevoloping countries. UN. Newyork. 1972;1(6):75-122.

18. Anonymous. Manual on development and use of FAO and WHO specifications for pesticides First edition - third revision March; 2016.

19. Miranova MK, Khorkhordin EG. Effect of Neem Azal T/S on Tetranychus urticae Koch. In Proceedings at the 5th Workshop. Wetzlar. Germany; $1996 ; 22-25$.

20. Anonymous. standard insecticides testing methods against vegetable pests.(Tetranychus urticae Koch. (Acari:Tetranychidae)). General Directorate of Agricultural Research and Policies. 2011;81.

21. Abbott WS. A method of computing the effectiveness of an insecticide. $J$ Econ. Entomol. 1925;18(2):265-267. 
22. Digillio V, Cristofora, M. Marchini DD, et al. Effects of a neem compound on the fecunditiy and longevity of cerstitis capitata (Diptera:Tephritidae) J Econ Entomol. 1999;92(1):76-82.

23. Singh RN, Saratchandra B. The development of botanical products with special reference to seri-ecosystem. Caspian Journal of Environment Science. 2005;3(1):1-8

24. Sertkaya E, Kammuran KK, Soylu S. Acaricidal activities of the essential oils from several medicinal plants against the carmine spider mite tetranychus cinnebarinus boisd (Acarina: Tetranchidae). Crop Prod. 2010;31:107-112.

25. Ahmed SGM, Hylin JW, Mitchell WC, et al. Investigating the feasibility of using botanical materials for pests control under traditional farming system: a suggested neem approach. In Proceedings of 2nd International Neem Conference. Rauischholzhausen. 1984;545-550.

26. Rambold H, Sharma GK, Czoppelt C, et al. Azadirachtin: A potent insect growth regulator of plant origin. Angewantede entomolgie banner. 1982;93(1-5):12-17.
27. Schmutterer H. Properties and potential of natural pesticides from the neem tree . Azadirachta indica. Annu Rev.Entomol. 1990; 35:271-297.

28. Dimetry NZ, Amer SAA, Reda AS. Biological activity of two neem seed kernel extracts against the two spotted spider mite Tetranychus urticae Koch. J Apply.Entomol. 1993;116:308-312.

29. Nadia Z, Dimitry SA, Amer A, et al. Biological activity of two-neem seed kernel extracts against the two-spotted spider mite Tetranychus urticae Koch. J Apply. Entomol. 1993;116:308-312.

30. Sundaram KMS, Sloane L. Effects of Pure and Formulated Azadirachtin. a Neem-Based Biopesticide. on the Phytophagous Spider Mite. Tetranychus urticae Koch. J Envir Sci Health. 1995;30:801-814.

31. Dabrowsky TZ, Seredynska U. Charactrisation of the two-spotted spider mite (Tetranychus urticae Koch. :Tetranychidae) responses to aqueous extracts from selected plant species. $J$ of Plant Protection Research. 2007;47(2):114-123.

32. Oelrichs BP, Hill M, Vallely PJ, et al. Toxic Tetranortriterpenes of the fruit of Melia azedarach L. Phytochemistry. 1983;22 (2):531-534. 